\title{
CAUSES OF LANGUAGE ANXIETY IN AN ESL CLASSROOM:
TOWARDS A MENTALLY HEALTHIER LEARNING ENVIRONMENT
}

(D) Salina Sabri ${ }^{1+}$
(iD) Zulaikha
Khairuddin $^{2}$
(iD) Syafiqah Johan
Amir Johan
(D) Khairunnisa Mohd
Daud $^{4}$
(D) Fatin Fatinah
Shamshul Bahrn $^{5}$

Article History

Received: 1 July 2021 Revised: 4 August 2021 Accepted: 8 September 2021 Published: 29 September 2021

\section{Keywords}

Language anxiety

Causes

Teaching style

Teaching strategies

ESL classroom

Mentally healthy learning

environment.

\author{
1,9,3,1,5 Akademi Pengajian Bahasa, Universiti Teknologi MARA, Shah Alam, \\ Selangor, Malaysia. \\ 'Email: salina619@uitm.edu.my Tel: +60195851805 \\ •Email: zulaikha5497@uitm.edu.my Tel:+60129564817 \\ ${ }^{s}$ Email: syafiqah@uitm.edu.my Tel: +60199304551 \\ Email: khair208@uitm.edu.my Tel: +60127332082 \\ ${ }^{5}$ Email:fatinfatinah@uitm.edu.my Tel: +60173385037
}

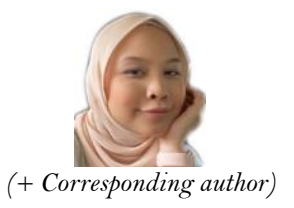

ABSTRACT

In a typical English language classroom, learners are expected to produce written sentences that are grammatically correct, and they are expected to sound native-like in their pronunciation. However, such expectations may cause anxiety and could potentially hinder the success of creating functional and successful language learners. This study aimed to understand undergraduate students' language learning anxiety and their perceived success in an ESL classroom in the hopes of creating a mentally healthier language learning environment. Through a quantitative approach, the results of the questionnaire showed that reasons that led to undergraduate students' anxiety in an ESL classroom were fear of tests, fear of comprehension, and fear of negative evaluation by peers. The results also showed that undergraduate students felt less anxious when lecturers provided non-threatening or mentally healthier environment for students to learn in their classroom. It can be concluded that a lecturer's teaching styles and strategies affected students' level of anxiety and can help ensure a mentally healthier language learning environment. From the findings, it is recommended that lecturers create a less formal and friendlier classroom atmosphere by providing psychological support and making students aware of the possible channels to seek help when needed.

Contribution/ Originality: This study contributes to the existing literature on language anxiety by providing evidence that educators' teaching strategies and styles can provide a mentally healthier environment in second language classrooms that will positively influence students' ability to learn.

\section{INTRODUCTION}

\subsection{Background of the Study}

English is a second language in Malaysia (Hashim, Yunus, \& Hashim, 2018) and therefore it is widely used in many aspects of Malaysians' social, professional, and academic lives. However, a large number of Malaysian graduates, despite having learnt English since kindergarten, lack the fluency to effectively communicate and function in the language (Miskam \& Saidalvi, 2018). In a typical English language classroom, learners are expected to produce written sentences that are grammatically correct, and they are expected to sound native-like in their 
pronunciation. Such expectations may cause reticence among learners to participate in classroom activities (Amengual-Pizarro, 2018). Even though studies may have suggested that learners' errors could yield positive results in foreign language learning classrooms (Gayo \& Widodo, 2018; Khansir \& Pakdel, 2019; Mushtaq, Mahmood, Ismail, Ahmad, \& Adeel, 2019), an understanding of the connection between anxious learners and the reaction to their errors could highly likely create a mentally healthier learning environment for learners of a second language (Zheng \& Cheng, 2018).

When students feel less anxious in a classroom environment, their inhibitions might be lowered, leading to a more successful language learning (Dewaele, Magdalena, \& Saito, 2019). Studies have demonstrated a real and significant link between mental health and the classroom learning environment (Dewaele, 2017; Dewaele \& Dewaele, 2018; Russell, 2020). Hence, a mentally healthy learning environment is critical for undergraduate students to feel safe emotionally and mentally and feel that their educators acknowledge their challenges during the learning process. Without a mentally healthy learning environment, these undergraduate students could be at risk to mental illness. Since educators have an obligation to protect the mental well-being of their learners, lessons should be approached with empathy in the hopes of creating more functional and successful second language learners.

\subsection{Statement of the Problem}

Anxiety is a condition that could hinder the success of learning a second and/or foreign language and empirical studies have been conducted to investigate the link between anxiety and its effects, be it positive or negative, in a second and/or foreign language learning classroom (Amengual-Pizarro, 2018; Horwitz, Horwitz, \& Cope, 1986; Martin \& Alvarez Valdivia, 2017; Young, 1991). However, regardless of the high number of studies conducted, a lack of empathy and understanding from educators could potentially hinder the success of creating functional and successful language learners (Oteir \& Al-Otaibi, 2019). As such, this study aimed to understand undergraduate students' language learning anxiety and their perceived success in an English as a Second Language (ESL) classroom, in the hopes of creating a mentally healthier language learning environment.

\subsection{Objectives of the Study}

This study attempts to show the level of language learning anxiety among undergraduate students and the teaching strategies preferred by them from their educators in ensuring the success of their second language learning. Hence, the two research questions that will be addressed are:

RQ1: What are the causes of language anxiety among undergraduate students?

RQ2: What are the teaching strategies lecturers could employ to provide a mentally healthier learning environment?

\section{LITERATURE REVIEW}

\subsection{Language Anxiety in ESL Classroom}

Anxiety is the "subjective feeling of tension, apprehension, nervousness, and worry associated with an arousal of the autonomic nervous system" (Spielberger, 1983, as cited in Horwitz et al., 1986). Anxiety might be a trait, a state, or situation-specific (Spielberger, 1983, as cited in Oteir \& Al-Otaibi, 2019). Oteir and Al-Otaibi (2019) explain how a person who displays traits of anxiety might be generally more predisposed to anxiety than others; a state of anxiety is anxiety induced by an emotional response due to perceived threat or danger regardless of the actual situation; while a situation-specific anxiety is directly influenced by the immediate context. In the second language classroom, Teimouri, Goetze, and Plonsky (2019) trace a trend where the early conceptualisation of second language anxiety as a trait has given way towards being situation-specific. This means that anxiety in a 
second language classroom is usually induced by external factors in the classroom itself, such as the activities, peers, and fear of being judged by others, rather than being constant.

Many studies attest to the effect of student perception of their abilities on their anxiety. When Alias and Noor Rashid (2018) measured the level of anxiety among higher and lower achievers in English classrooms of a polytechnic in Terengganu, Malaysia, they found no significant difference between the two groups. However, the result suggests that the weaker students are more anxious about being judged by others, especially in oral tests and role plays. Another study done on a group of polytechnic students in Negeri Sembilan, Malaysia finds that learners' anxiety is moderately linked to their beliefs about language learning (William Tandang \& Mohd Arif, 2019). Clearly, beliefs about language learning can impact students' ability to learn as the study further shows that second language achievement is negatively related with levels of anxiety. Genç and Yayli (2019) found that Turkish learners of B2 level on the Common European Framework of Reference for Languages (CEFR) experience high anxiety during writing tasks despite their relatively high level of English. They posit that learners' perception of their own competence and ability might affect the level of anxiety.

\subsection{Causes of Language Anxiety in ESL Classroom}

Thus, not only might their second language learning ability be impacted by anxiety, learners' anxiety in a second language classroom is largely situation-specific. Through a structured interview and focus-group discussion, Hashimi (2011) explores the factors of anxiety of 60 Iranian students undertaking English as a Foreign Language (EFL) in English translation and literature. The findings show that due to the formal classroom environment, most learners experience high levels of language anxiety. According to the participants of the study, classroom environments that involve collaborative learning activities between teachers and students are less likely to provoke anxiety and stress. In addition, the need to be more correct and clearer in using English is another factor of the existence of language anxiety among the research participants. Similarly, a study by Fatmawati, Haura, and Supiani (2020), which investigates the causes that affect EFL students' confidence in speaking English at MEC English Course Banjarmasin through interview sessions and a qualitative analysis, found that apart from feeling restless, the students feel worried that the educators and classmates would negatively judge them when speaking in English. This means that these students fear they would make mistakes when using English in front of the class.

Besides the general second language classroom condition, specific learning tasks may cause anxiety. In an attempt to investigate the existence of reading anxiety among 13 Arabic high school English language learners, Kress (2015) employs both quantitative and qualitative methods. Through observation and interview sessions, he finds that the anxiety level of the learners increased when they encountered unknown vocabulary and unfamiliar topics. Another finding of this study is also in congruence with the previous studies mentioned above in terms of fear of making errors. In their quantitative study on the link between anxiety and writing, Genç and Yayli (2019) find that relatively competent Turkish learners employ avoidance behaviour when asked to write in English. Having to find supporting ideas is listed as being "most anxiety-provoking", while unfamiliar writing topics along with time restrictions are other causes of anxiety during writing tasks (Genç \& Yayli, 2019).

\subsection{Mentally Healthier Learning Environment}

The existence of language anxiety has been discussed by many researchers. Strategies to create a mentally healthier learning environment have also been deliberated to help learners be more comfortable in learning English as a second language. Tanveer (2008) reports that language anxiety exists due to lack of chances given to students to practice speaking in class. It was suggested that students should be provided with an informal and cooperativelearning environment. A majority of Hashimi (2011) research subjects suggest that educators create a less formal classroom environment, motivate learners so they would feel comfortable in using English, and incorporate collaborative learning activities (role-play) during their teaching and learning sessions. 
A study conducted by Sabbah (2018) analyses the causes of language anxiety among first-year ESL students of Community College of Qatar. Through the distribution of Five-Likert 40-item questionnaires to 70 female students, the researcher finds several causes of language anxiety and suggests a number of plans of action for instructors, administrators, and students to overcome the issue. Apart from creating a more relaxed learning environment, educators could adopt error-correction strategies, help build students' self-confidence, and incorporate a sense of humor in class to reduce the level of anxiety of students. As for the learners, the researcher highlights that having good study habits, learning relaxation techniques, and studying daily could help eliminate anxiety when learning English. Lastly, collaboration between administrators of college and instructors, using a case-solving approach, and leniency when it comes to class attendance are highly encouraged at the administrative level.

\section{METHODOLOGY}

This study used a quantitative approach. The research design utilised in this study was descriptive research. The instrument used in this study was questionnaire. The questionnaire was adapted from Sabbah (2018) and there were 6 parts with 35 items in total. Firstly, part A was on 'demographic details'. Secondly, part B was on 'fear of comprehension'. Thirdly, part C was on 'fear of tests'. Fourthly, part D was on 'fear of negative evaluation by ELC lecturers'. Fifthly, part E was on 'fear of negative evaluation by peers' and lastly, part F was on 'ELC lecturers' teaching styles'. The population of this study was 163 students from one of the public universities in Malay sia who were given around 2 weeks to complete the questionnaire. The data was analysed via SPSS v27. The data reported in the form of tables and portrayed the frequency, mean, and standard deviation.

\section{FINDINGS}

4.1. RQ1: What are the Causes of Language Anxiety among Undergraduate Students?

Table-1. Fear of test

\begin{tabular}{l|c|c}
\hline & Mean & Std. Deviation \\
\hline $\begin{array}{l}\text { I get worried when I know my grades in my undergraduate subjects are } \\
\text { determined by assignments and assessments that are written in English. }\end{array}$ & 3.33 & 1.144 \\
\hline $\begin{array}{l}\text { I get nervous about possibly receiving lower scores when taking English } \\
\text { listening tests. }\end{array}$ & 3.85 & 1.079 \\
\hline $\begin{array}{l}\text { I am afraid that I can't complete all the questions within the specified time due } \\
\text { to my slow reading speed. }\end{array}$ & 3.42 & 1.186 \\
\hline I worry that my writing speed is too slow when I take English writing tests. & 3.65 & 1.114 \\
\hline $\begin{array}{l}\text { I fear that my performance in my English-speaking test is not satisfying } \\
\text { because of my poor speaking skills. }\end{array}$ & 3.85 & 1.034 \\
\hline Fear of Test & 3.62 & 0.901 \\
\hline
\end{tabular}

Table 1 illustrates the results of the first reason that leads to students' language anxiety which is 'Fear of Test'. It can be seen that the highest mean score $3.85(\mathrm{SD}=1.034 ; 1.079)$ is obtained by 'I fear that my performance in my English speaking test is not satisfying because of my poor speaking skills.' and 'I get nervous about possibly receiving lower scores when taking English listening tests.'. Next, the mean score for 'I worry that my writing speed is too slow when I take English writing tests.' is 3.65 ( $\mathrm{SD}=1.114)$, followed by 'I am afraid that I can't complete all the questions within the specified time due to my slow reading speed.' $(\mathrm{M}=3.42 ; \mathrm{SD}=1.186)$. The lowest mean score is attained by 'I get worried when I know my grades in my undergraduate subjects are determined by assignments and assessments that are written in English.' $(\mathrm{M}=3.33 ; \mathrm{SD}=1.144)$. Overall, the mean score for 'Fear of Test' is $3.62(\mathrm{SD}=0.901)$. This means that respondents somewhat agree that they were concerned about their performance in English language for all four skills during assessments. 
Table-2. Fear of Comprehension.

\begin{tabular}{l|c|c}
\hline & Mean & Std. Deviation \\
\hline $\begin{array}{l}\text { I am afraid that some ELC lecturers want me to study independently without } \\
\text { their explanation. }\end{array}$ & 3.46 & 1.124 \\
\hline $\begin{array}{l}\text { It frightens me when I don't understand what the lecturer is saying in an ELC } \\
\text { class. }\end{array}$ & 3.44 & 1.089 \\
\hline $\begin{array}{l}\text { I worry that my English listening ability is not good, and this affects my } \\
\text { understanding. }\end{array}$ & 3.51 & 1.173 \\
\hline $\begin{array}{l}\text { I was not exposed to a variety of academic reading materials in English prior } \\
\text { to my undergraduate programme. }\end{array}$ & 2.62 & 1.044 \\
\hline $\begin{array}{l}\text { I am afraid I did not get enough practice on written texts skills prior to my } \\
\text { undergraduate programme. }\end{array}$ & 3.47 & 1.085 \\
\hline $\begin{array}{l}\text { I worry that I cannot understand the different accents used by different ELC } \\
\text { lecturers. }\end{array}$ & 3.17 & 1.156 \\
\hline Fear of Comprehension & 3.28 & 0.809 \\
\hline
\end{tabular}

Table 2 portrays the results for the second reason that leads to students' language anxiety which is 'Fear of Comprehension'. 'I worry that my English listening ability is not good, and this affects my understanding.' obtained the highest mean score which is 3.51 ( $\mathrm{SD}=1.173)$. Next, the mean score for 'I am afraid I did not get enough practice on written texts skills prior to my undergraduate programme.', 'I am afraid that some ELC lecturers want me to study independently without their explanation.' and 'It frightens me when I don't understand what the lecturer is saying in an ELC class.' are $3.47(\mathrm{SD}=1.085), 3.46(\mathrm{SD}=1.124)$, and $3.44(\mathrm{SD}=1.089)$ respectively. 'I worry that I cannot understand the different accents used by different ELC lecturers.' obtained a mean score of 3.17 $(\mathrm{SD}=1.156)$. The lowest mean score $(\mathrm{M}=2.62 ; \mathrm{SD}=1.044)$ is obtained by 'I was not exposed to a variety of academic reading materials in English prior to my undergraduate programme.'. The overall mean score for 'Fear of Comprehension' is 3.28 ( $\mathrm{SD}=0.809)$. Hence, it can be said that respondents were anxious about their understanding when learning the language and the skills.

Table-3. Fear of negative evaluation by lecturer.

\begin{tabular}{l|c|c}
\hline & Mean & Std. Deviation \\
\hline $\begin{array}{l}\text { I worry my ELC lecturer might have negative feelings about me due to my bad } \\
\text { performance on English tests. }\end{array}$ & 3.64 & 1.127 \\
\hline $\begin{array}{l}\text { I worry that my ELC lecturer is biased and unfair in correcting our assignments } \\
\text { and assessments. }\end{array}$ & 2.90 & 1.268 \\
\hline Some ELC lecturers' negative words hinder my progress. & 2.63 & 1.267 \\
\hline $\begin{array}{l}\text { I am afraid that my ELC lecturer highlights my errors (pronunciation and } \\
\text { grammar) in the class. }\end{array}$ & 2.77 & 1.210 \\
\hline $\begin{array}{l}\text { I fear that my ELC lecturer might embarrass me in front of the class because of } \\
\text { my poor command of English. }\end{array}$ & 2.87 & 1.315 \\
\hline Fear of Negative Evaluation by Lecturer & 2.96 & 0.976 \\
\hline
\end{tabular}

Table 3 shows the results of 'Fear of Negative Evaluation by Lecturer'. The highest mean score is 3.64 $(\mathrm{SD}=1.127)$ for 'I worry my ELC lecturer might have negative feelings about me due to my bad performance on English tests.' 'I worry that my ELC lecturer is biased and unfair in correcting our assignments and assessments.', 'I fear that my ELC lecturer might embarrass me in front of the class because of my poor command of English.' and 'I am afraid that my ELC lecturer highlights my errors (pronunciation and grammar) in the class.' obtained the mean score of $2.90(\mathrm{SD}=1.268), 2.87(\mathrm{SD}=1.315)$, and $2.77(\mathrm{SD}=1.210)$ respectively. The lowest mean score $(\mathrm{M}=2.63 ; \mathrm{SD}=1.267)$ is obtained by 'Some ELC lecturers' negative words hinder my progress.'. The overall mean score for 'Fear of Negative Evaluation by Lecturer' is $2.96(\mathrm{SD}=.976)$. Thus, it can be concluded that respondents disagree that they were nervous about their lecturers' evaluation in the classroom. 
Table-4. Fear of negative evaluation by peer.

\begin{tabular}{l|c|c}
\hline & Mean & Std. Deviation \\
\hline $\begin{array}{l}\text { I feel shy to speak in English because I was not exposed to English } \\
\text { speaking environment prior to my undergraduate programme. }\end{array}$ & 3.02 & 1.235 \\
\hline $\begin{array}{l}\text { I get stressed when I know I will have to speak in English in front of my } \\
\text { classmates. }\end{array}$ & 3.01 & 1.274 \\
\hline $\begin{array}{l}\text { I feel awkward when I have to speak in English in front of unfamiliar } \\
\text { people in ELC classes. }\end{array}$ & 3.38 & 1.306 \\
\hline I worry that the other students speak English better than I do. & 3.41 & 1.275 \\
\hline $\begin{array}{l}\text { I fear being laughed at by others because I might make errors in } \\
\text { pronunciation and grammar, so I don't dare to ask questions even when I } \\
\text { have questions. }\end{array}$ & 3.26 & 1.342 \\
\hline Fear of Negative Evaluation by Peer & 3.22 & 1.098 \\
\hline
\end{tabular}

Table 4 displays the results of 'Fear of Negative Evaluation by Peer'. The highest mean score is obtained by 'I worry that the other students speak English better than I do.' with 3.41 ( $\mathrm{SD}=1.275)$. Next, the mean scores for 'I feel awkward when I have to speak in English in front of unfamiliar people in ELC classes.', 'I fear being laughed at by others because I might make errors in pronunciation and grammar so I don't dare to ask questions even when I have questions.' and 'I feel shy to speak in English because I was not exposed to English speaking environment prior to my undergraduate programme.' are $3.38(\mathrm{SD}=1.306), 3.26(\mathrm{SD}=1.342)$, and $3.02(\mathrm{SD}=1.235)$ respectively. The lowest mean score is obtained by 'I get stressed when I know I will have to speak in English in front of my classmates.' with 3.01 ( $\mathrm{SD}=1.274)$. The overall mean score for 'Fear of Negative Evaluation by Peer' is 3.22 (1.098). Based on the results, it can be said that respondents somewhat agreed that they were anxious about being evaluated by their peers.

4.2. RQ2: What are the Scaffolding Strategies Lecturers Could Employ to Provide a Mentally Healthier Learning Environment?

Table-5. Student's preference on lecturer's teaching style.

\begin{tabular}{l|c|c}
\hline & Mean & Std. Deviation \\
\hline I like it when my ELC lecturer makes the class less formal and friendlier. & 4.69 & 0.570 \\
\hline $\begin{array}{l}\text { I like it when my ELC lecturer has more speaking activities (e.g. drama, role } \\
\text { play, etc.). }\end{array}$ & 3.98 & 1.094 \\
\hline $\begin{array}{l}\text { I like it when my ELC lecturer conducts more group activities (e.g. group } \\
\text { discussions, collaborative learning, etc.). }\end{array}$ & 4.06 & 0.973 \\
\hline $\begin{array}{l}\text { I like it when my ELC lecturer corrects students' errors with non-threatening } \\
\text { techniques (e.g. focus on students' strengths instead of weaknesses, promote } \\
\text { two-way respect, etc.). }\end{array}$ & 4.57 & 0.598 \\
\hline I like it when my ELC lecturer focusses on fluency over accuracy. & 4.12 & 0.804 \\
\hline I like it when my ELC lecturer allows room for errors. & 4.43 & 0.720 \\
\hline $\begin{array}{l}\text { I like it when my ELC lecturer is not judgmental when I make mistakes in } \\
\text { English. }\end{array}$ & 4.66 & 0.590 \\
\hline I like it when my ELC lecturer is understanding of my situation. & 4.71 & 0.541 \\
\hline
\end{tabular}

Table 5 depicts the results of 'Student's Preference on Lecturer's Teaching Style'. The highest mean score is obtained by 'I like it when my ELC lecturer is understanding of my situation.' with 4.71 (SD=.541), followed by 'I like it when my ELC lecturer makes the class less formal and friendlier.' with $4.69(\mathrm{SD}=.570)$. The mean scores for 'I like it when my ELC lecturer is not judgmental when I make mistakes in English.', 'I like it when my ELC lecturer corrects students' errors with non-threatening techniques (e.g. focus on students' strengths instead of weaknesses, promote two-way respect, etc.).', and 'I like it when my ELC lecturer allows room for errors.' are 4.66 $(\mathrm{SD}=.590), 4.57$ ( $\mathrm{SD}=.598)$, and 4.43 ( $\mathrm{SD}=.720)$ respectively. 'I like it when my ELC lecturer focusses on fluency over accuracy.' obtained the mean score of $4.12(\mathrm{SD}=.804)$ followed by 'I like it when my ELC lecturer conducts 
more group activities (e.g. group discussions, collaborative learning, etc.).' with the mean score of 4.06 ( $\mathrm{SD}=.973$ ). The lowest mean score is obtained by 'I like it when my ELC lecturer has more speaking activities (e.g. drama, role play, etc).' with $3.98(\mathrm{SD}=1.094)$. Based on the results, it is believed that respondents preferred the lecturers to scaffold them in their learning with a mentally healthier environment.

\section{CONCLUSION}

5.1. Summary of Findings

Based on the results, it can be concluded that the factors that cause students to be anxious when learning English in an ESL classroom are 'Fear of Test', 'Fear of Comprehension', and 'Fear of Negative Evaluation by Peers'. 'Fear of Test', which can be translated as test anxiety, is quite common among students who are learning any subjects especially those who are learning English as their second or foreign language. The result of this study mirrors a research done by Aydin, Denkci Akkaş, Türnük, Baştürk Beydilli, and Saydam (2020) who discovered that students were anxious due to fear of failure. This indicates that students were distressed about their performance in their language test. Another cause is the 'Fear of Comprehension', which means that the students were nervous that they might not understand what the lecturer is explaining. The result of the current study is in line with a study done by Anggraeny, Said, and Febriani (2020) that states that the majority of students were apprehensive when they were unable to comprehend the lesson in the class. This is because inability to understand a lesson will affect their performance in the assessments or assignments.

Furthermore, the result shows that respondents felt uneasy about being evaluated by their peers. Interestingly, a study done by Nawas (2020) found that students in his study were more concerned about self-assessment compared to peer assessment. This may be due to a different setting and place from the current study. Moreover, the current study revealed quite fascinating findings where students were not apprehensive towards negative evaluation by lecturers. This result contradicts a study done by Jugo (2020) where students were nervous about being corrected while communicating in English by educators. The different result may stem from a group of lecturers from the current study who had provided a non-threatening or mentally healthier environment for students to learn in their classrooms. This can be seen from the participants' responses on their preference of lecturer's teaching style where they preferred to have friendlier and less formal instructors who focus on fluency in class. This can be supported by a study done by Inada (2021) which states that educators need to provide students with a non-threatening or mentally healthier environment while using scaffolding techniques to facilitate students' learning. It can be concluded that a lecturer's teaching styles and strategies can affect students' level of anxiety.

\subsection{Pedagogical Implications}

This study reveals that there are potential stressful situations that lead to students' anxiety, thus affecting the learning environment and their mental health. In order to help students cope with language learning anxiety, lecturers can facilitate by understanding the students' distress factors and then developing scaffolding strategies that will buoy up learners in a healthier language learning environment. Most respondents mentioned that they are anxious about their performance in English tests. It is understood that their performance on tests affects their cumulative grade point average (CGPA) for the whole duration of study, thereby putting some strain on them when sitting for tests. These burdens, if not attended to, may cause burnout and affect students' motivation in learning. Hence, it is recommended that lecturers create a less formal and friendlier classroom atmosphere by providing psychological support and making the students aware of the possible channels to seek help when needed.

Also evident in the responses is the fear of comprehension when learning the four language skills can be induced by studying independently without a lecturer's guidance. To overcome this, it is recommended for lecturers to be understanding of the students' situation and to be approachable, which may encourage students to seek help if they are lost rather than practise avoidance strategies. As students' low confidence level when learning English is 
also affected by fear of negative evaluation by their friends, it is proposed that lecturers utilise cooperative activities such as role-play, group assignments, and group presentations. Encouraging anxious and non-anxious students students to work in groups will help lessen their anxiety as they will enjoy more opportunities to use the language in a non-threatening context (Tsiplakides \& Keramida, 2009).

\subsection{Suggestions for Future Research}

Future studies can further investigate this topic by looking at other aspects related to mentally healthier language learning environment, for example by focusing on ways to reduce language anxiety, as well as the effects of language anxiety. It is also suggested that other studies on language anxiety and mentally healthier classroom environment in Malaysia should consider collecting data by means of qualitative interviews to gain better understanding of students' perception on the causes of language anxiety in since they will be able to provide their opinions on the matter.

Funding: This study received no specific financial support.

Competing Interests: The authors declare that they have no competing interests.

Acknowledgement: All authors contributed equally to the conception and design of the study.

\section{REFERENCES}

Alias, A., \& Noor Rashid, N. A. (2018). The relationship between students' second language learning anxiety and language proficiency. Journal of Counseling and Educational Technology, 1(2), 50-58. Available at: https://doi.org/10.32698/0141.

Amengual-Pizarro, M. (2018). Foreign language classroom anxiety among English for Specific purposes (ESP) students. International Journal of English Studies, 18(2), 145-159. Available at: https://doi.org/10.6018//ijes/2018/2/323311.

Anggraeny, D., Said, I., \& Febriani, R. B. (2020). The EFL students' perception of their foreign language anxiety in speaking class. Journal of Educational Forum, 7(1), 29-38. Available at: http://dx.doi.org/10.25157/wa.v7i1.3123.

Aydin, S., Denkci Akkaş, F., Türnük, T., Baştürk Beydilli, A., \& Saydam, I. (2020). Test anxiety among foreign language learners: A qualitative study. The Qualitative Report, 25(12), 4289-4309. Available at: https://doi.org/10.46743/21603715/2020.4686.

Dewaele, J. (2017). Are perfectionists more anxious foreign language learners and users? In C. Gkonou, M. Daubney, \& J.-M. Dewaele (Eds.), New insights into language anxiety: Theory, research and educational implications (pp. 70-91). Bristol: Multilingual Matters.

Dewaele, J., \& Dewaele, L. (2018). Learner-internal and learner-external predictors of willingness to communicate in the FL classroom. Journal of the European Second Language Association, 2(1), 24-37. Available at: https://doi.org/10.22599/jesla.37.

Dewaele, J. M., Magdalena, A. F., \& Saito, K. (2019). The effect of perception of teacher characteristics on Spanish EFL learners' anxiety and enjoyment. The Modern Language Journal, 103(2), 412-427. Available at: https://doi.org/10.1111/modl.12555.

Fatmawati, M., Haura, R., \& Supiani. (2020). Factors affecting EFL learners' confidence in speaking English at the MEC English Course Banjarmasin. Paper presented at the International Conference on Social Sciences \& Humanities, Economics, Politics.

Gayo, H., \& Widodo, P. (2018). An analysis of morphological and syntactical errors on the English writing of the junior high school Indonesian students. International Journal of Learning, Teaching and Educational Research, 17(4), 58-70. Available at: https://doi.org/10.26803/ijlter.17.4.4.

Genç, E., \& Yayli, D. (2019). The second language writing anxiety: The perceived sources and consequences. Pamukkale University Journal of Education Faculty, 45, 235-251. Available at: https://doi.org/10.9779/PUJE.2018.231.

Hashim, H. U., Yunus, M. M., \& Hashim, H. (2018). Language learning strategies used by adult learners of teaching English as a second language (TESL). TESOL International Journal, 13(4), 39-48. 
Hashimi, M. (2011). Language stress and anxiety among the English language learners. Procedia-Social and Behavioral Sciences, 30, 1811-1816. Available at: https://doi.org/10.1016/j.sbspro.2011.10.349.

Horwitz, E. K., Horwitz, M. B., \& Cope, J. (1986). Foreign language classroom anxiety. The Modern Language Journal, 70(2), 125132. Available at: https://doi.org/10.2307/327317.

Inada, T. (2021). Teachers' strategies for decreasing students' anxiety levels to improve their communicative skills. English Language Teaching, 14(3), 32-41. Available at: https://doi.org/10.5539/elt.v14n3p32.

Jugo, R. R. (2020). Language anxiety in focus: The case of Filipino undergraduate teacher education learners. Education Research International, 1-8. Available at: https://doi.org/10.1155/2020/7049837.

Khansir, A. A., \& Pakdel, F. (2019). Contrastive analysis hypothesis and second language learning. Journal of ELT Research, 4(1), 35-43. Available at: http://dx.doi.org/10.22521/edupij.2018.73.3.

Kress, M. (2015). Reading anxiety among Arabic speaking students. Master's Thesis.

Martin, S., \& Alvarez Valdivia, I. M. (2017). Students' feedback beliefs and anxiety in online foreign language oral tasks. International Journal of Educational Technology in Higher Education, 14(1), 1-15. Available at: https://doi.org/10.1186/s41239-017-0056-z.

Miskam, N. N., \& Saidalvi, A. (2018). Investigating English language speaking anxiety among Malaysian undergraduate learners. Asian Science Social, 15(1), 1-7. Available at: https://doi.org/10.5539/ass.v15n1p1.

Mushtaq, M., Mahmood, M. A., Ismail, M. K. A., Ahmad, M., \& Adeel, H. M. (2019). A corpus-based analysis of EFL learners' errors in written composition at intermediate level. Indian Journal of Natural Sciences, 9(52), 16842-16852.

Nawas, A. (2020). Grading anxiety with self and peer-assessment: A mixed-method study in an Indonesian EFL context. Issues in Educational Research, 30(1), 224-244.

Oteir, I. N., \& Al-Otaibi, A. N. (2019). Foreign language anxiety: A systematic review. Arab World English Journal (AWEJ), 1O(3), 309-317.

Russell, V. (2020). Language anxiety and the online learner. Foreign Language Annals, 53(2), 338-352. Available at: https://doi.org/10.1111/flan.12461.

Sabbah, S. S. (2018). Anxiety in learning English as a second language at a tertiary stage: Causes and solutions. European Journal of English Language and Literature Studies, 6(1), 14-33.

Tanveer, M. (2008). Investigation of the factors that cause language anxiety for ESL/EFL learners in learning speaking skills and the influence it casts on communication in the target language. Master's Thesis.

Teimouri, Y., Goetze, J., \& Plonsky, L. (2019). Second language anxiety and achievement: A meta-analysis. Studies in Second Language Acquisition, 41, 363-387. Available at: https://doi.org/10.1017/S0272263118000311.

Tsiplakides, I., \& Keramida, A. (2009). Helping students overcome foreign language speaking anxiety in the English classroom: Theoretical issues and practical recommendations. International Education Studies, 2(4), 39-44.

William Tandang, T., \& Mohd Arif, M. (2019). Beliefs about second language learning, role of gender and students' achievement in relation to second language anxiety. Asian Journal of University Education (AJUE), 15(3), 276-284. Available at: https://doi.org/10.24191/ajue.v15i3.7813.

Young, D. J. (1991). Creating a low-anxiety classroom environment: What does language anxiety research suggest? Modern Language Journal, 75(4), 26-436. Available at: https://doi.org/10.2307/329492.

Zheng, Y., \& Cheng, L. (2018). How does anxiety influence language performance? From the perspectives of foreign language classroom anxiety and cognitive test anxiety. Language Testing in Asia, 8(13). Available at: https://doi.org/10.1186/s40468-018-0065-4.

Views and opinions expressed in this article are the views and opinions of the author(s), International Journal of Asian Social Science shall not be responsible or answerable for any loss, damage or liability etc. caused in relation to/arising out of the use of the content. 